\title{
TRADE UNIONISM, COLLECTIVE BARGAINING AND NATION BUILDING: THE NIGERIAN EXPERIENCE
}

\section{Charles N. Okolie}

\section{Introduction}

It is a well known fact that the growth and development of any nation depends on the structures it has carved out for itself. In Nigeria, amidst the various arms of the government which has been working tirelessly to ensure the growth and sustenance of the Nigerian state is the emergence of trade unions. The colonial influence in Nigeria has left much to be desired. The emergence of these trade unions has become a desired form of association in order to restore the dignity of professional workers and more so ensure greater level of overall national output which is part of nation building. These unions operate on different levels depending on their modus operandi. They use different means to press home their needs seeking for recognition in the political sphere. To ensure peace and as part of the process of resolving any industrial dispute, the unions in dispute often enter into some kind of collective bargaining with the government or agency involved. Over the years these trade unions have preserved in their collective efforts to maintain a standardized culture in the labour market. This stems from the clarion call by the nationalist movement for collective co-operation and nation building. The impact of these trade unions on the Nigerian government cannot be over emphasized. Their persistent push and prowess have always put the government/agencies on their toes hoping to meet the workers demands for improved national output and national development. This paper tends to examine the impact of trade unionism and collective bargaining for Nigerian development.

\section{Origin and Development of Trade Unionism in Nigeria}

The term trade union has a variety of meanings depending on the perception of workers and the definition imposed by legal frameworks in many countries. According to Fajana, Trade unions laws in the UK and Nigeria defines trade union as: ... any combination whether temporary or permanent, the principal objectives of which its constitution are ... the regulation of the 
relation between workmen and workmen or between masters and masters or the imposing of restrictive conditions on the conduct of any trade or business and also the provision of benefits to members (132).

From the definition, employers associations are also to be regarded as trade unions. Trade unions are the main power resource of working people. The power in this collectivity of workers can promote the resolution of a variety of problems faced by the workforce and which help in nation building. Generally, the role of unions to their members includes economic, social, welfare, political, psychological benefits and opportunity to participate in managerial functions in the industry. Apart from the enlarged role of trade unions in the development of the society, the most important function of unions is the provision of economic benefits to their members.

Historically, there has been organization of workers in Nigeria before the advent of modern trade unionism. The trade unions in the former British colonies including Nigeria were not natural developments as in the metropolitan countries but rather a creature of the then British colonial office. This fact not withstanding, there is no evidence to show that the British government deliberately imported trade unionism in Nigeria but it could be said that the development of trade unions in Nigeria may have been influenced by events elsewhere. In the view of Yesufu, the experience in Sierra Leone greatly influenced the development of trade unionism in Nigeria. According to him the first union was not formed by a group of disaffected workers who wanted a platform from which to fight for amelioration of grievances or for the improvement of specific conditions of employment but rather it was formed just to conform to what workers in Sierra Leone has done. (Ubeku, 59).

There has been a long history of trade unionism. The first organization that is known to have had an interest in trade union activities was the mechanics mutual aid provident and mutual improvement association formed in July 1883. But the first trade union that is characterized by wage employment was the Nigerian service union organized in 1912. The union was more concerned with efficiency in the civil service and intensified nationalization of the service than with hard core trade unionism. Some other ones 
includes the railway workers union and the Nigerian union of teachers. Those who formed the railway workers union were dissenters from the civil service union. The reason for this break away of the railway workers to form the workers union was because they believed that the civil service union was too soft spoken on fundamental issues and more so, the civil service union was not responsive to the economic dictates of the period. More so because the new unions were made up of skilled workers or artisans in various trade, they were placed on a strategic position and so a strike by them could paralyse the economy.

As an offspring of this association of skilled workers, the NUT was formed. The reason for the formation was that the teachers were dissatisfied over conditions of employment. The African leaders were not happy that the working conditions in the mission schools were poorer than those of their contemporaries in the government owned institutions. Thus this grievance led to the formation of the union.

The interest of the unions was to promote national development and as a professional workers organization, the NUT was formed partly to carry out the regulatory functions of the teaching profession and to be a watch dog of the government educational policy. This development is equally true of the Nigerian Medical Association which in addition to promoting the economic well being of the members also help to promote a healthy nation.

The conglomeration of these unions helped in maintaining stability in the nation's economy. The militancy of the union workers as regards government unfavourable policies created a catastrophic phase of labour unrest and this led to a successful general strike in 1945. To ensure a sustained harmonization of the various unions, a central union was formed and this was called Trade Union Congress of Nigeria (TUCN). The congress demanded increase employment through intensified industrialization, nationalization of all public utilities and the establishment of labour party (Fashoyin, 23).

From facts gathered, it showed that many central labour organizations were formed between 1942-1975. These unions proffered strategies for sustained trade unionism, promotion of workers welfare and the generalized magnitude of national 
development. It is worthy to note that the rise of unionism was aided by the nationalist leaders struggle to rid the economy of bad leadership. Thus trade unionism and nationalism provided the basis for group collectivism in satisfying this particular objective.

However, due to the proliferation of trade unions, there was need to have a centralized organization of these various trade unions. This led to the formation of the Nigerian Labour Congress (NLC) in 1975. This became the strong backbone of the other unions. It coordinates the affairs of all these unions and these unions are deemed to be affiliated to the NLC. There were some specifications and guidelines in the procedure for such affiliation. The NLC became the centre force between the government and the various trade unions affiliated to it. The affiliated trade unions must make some reservations to the NLC from the monies collected from their members. It is the NLC that has in a long run intervened in the government face off with the skilled/professional workers in the country. Given the central organization of trade unions, any union which fails to pay its contribution is guilty of an offence and liable on conviction to a fine of twice the amount of the contribution. The NLC waxed very strong despite the incessant harassments, detention and intimidation on the leaders by the various governments especially during the military regime of Abacha and the Obasanjo led democratic government. NLC under the famous labour leader Comrade Adams Oshomole suffered a similar fate as the government nearly caused an unhealthy disintegration of the various unions affiliated to NLC.

As earlier noted, given the provision that all trade unions must be affiliated to the NLC some exceptions were given to some senior staff skilled/professionals like the Academic Staff Union of Universities (ASUU) which until the recent plea of re-affiliation to NLC has remained a separate trade union that tends to fight for the welfare of its members for effective performance and more so for national development cum nation building. The NLC's influence on ASUU was only on persuasive nature. The government's plot to polarize ASUU led to the disengagement from service of about 49 Unilorin lecturers for failure to break the strike over the non implementation of the December 2001 agreement. This action rather than disintegrate ASUU strengthened the union and the union at 
different intervals have called off its members to embark on strike seeking for redress and re-engagement of those lecturers. The fight lingered until the recent pronouncement by the supreme court in favour of the union. The union has continued to press on the government for better funding, proper remuneration, research grants, upliftment of the educational sector and the general welfare of its members.

We must note that these trade unions are structured in such a way that it gives protection to its members in cases of breach of contractual agreement between them and the authorities concerned while not forgetting its enduring task of fostering national development.

\section{Collective Bargaining and the Influence of Government on Its Enforcement}

Collective bargaining is a term that has been used by Sydney and Beatrice Web to describe negotiations on conditions of service and terms of employment between employers and workers or between employers associations and trade unions. (50) It covers all arrangements in which workers do not negotiate with employers by themselves but do so collectively through their representatives. The issues covered by such collective bargaining are always very extensive and they include wages hours of work, increments, promotions, job grading and classification, annual leave etc. In fact in the present dispensation, any matter which is capable of causing a trade dispute is negotiable. It has also been extended to sociopolitical matters like the election tribunal. (Sydney and Beatrice, 52)

It has been argued that the terms which trade unions seek to get through collective bargaining, the process by which they are negotiated and the enforcement of the agreement, all depend on the size and strength of the bargaining unit. In the public sector, collective bargaining take place at the national level. If the issues involved pertain to the whole nation, but if they concern a particular state only, the bargaining takes the procedure adopted in the private sector. (Sydney and Beatrice, 53) More so issues affecting the whole country that is those which involve both the federal and state governments are discussed between representatives of the federal and state governments and those of the Nigerian Labour Congress 
(NLC) or agency. Decisions reached at such negotiations are usually implemented by the parties involved.

In Nigeria, the issue of collective bargaining was provided for under the labour Act Cap 198 Laws of the Federation 1990. Collective bargaining was defined by the Act as the process of arriving or attempting to arrive at a collective agreement while collective agreement means, "an agreement in writing regarding working conditions and terms of employment concluded between;

a. an organization of workers or an organization representing workers (or an association of such organization of the one part and

b. an organization of employers or an organization representing workers (or an association of such organizations) of the other part (S. 91, Labour Act 1990).

However S.47 of the trade dispute Act 1990 provided a contrast definition. This not withstanding both definitions refers to collective bargaining as negotiations between employers and their employees collectively, represented by unions, for the settlement of terms and conditions of employment. The end result is an agreement. As an aspect of labour relations, collective bargaining provide the forum for a bargain or negotiation and lead eventually to rule making or agreement between the parties, thus creating some form of social order in the relationship (Erugo, 174).

Collective bargaining requires patience by the parties bargaining because it is usually long and tortuous and results are normally unpredictable. Decisions are reached after discussions. Such decisions are arrived at by unanimity and parties usually agree that while negotiations are in progress, there should be no strike or lockouts and that participants on the union side should not be victimized for their part in the negotiations. The government rarely intervenes in collective bargaining and if voluntary negotiations break down, parties are expected to follow the requirement of the trade disputes Decree No 7 of 1990 that provides for a voluntary collective bargaining and parties are required by the decree to exhaust their grievance procedures where they exist before resorting to other methods of dispute resolution. From the above facts, 
collective bargaining to a certain degree does work in Nigeria. It is seen as a national alternative to strike and lockouts in the midst of collective bargaining.

As earlier stated, the government does not intervene in any collective bargaining. The government merely acts as a watch dog for the enforceability of any agreement reached. More often than not most negotiations are entered into by an agent of the government on its behalf as well as the employees of the government. The main aim is not to make the government a judge in their own case which will defeat the principle of public policy. The agents acting on the permission of the government can contract on her behalf and the government must be willing to be bound by such agreement and of course effect its enforceability. The government must maintain its status as a regulatory body and ensure that agreements entered on her behalf are carried out successfully.

\section{Nation Building and National Development}

Generally, the concept of nation building paints a picture of some kind of building with real brick and mortar but in this case the edifice is the nation and not an ordinary house. The idea of nation building in this sense shows that everybody must work hand in hand to ensure that the well being of the people are maintained. The people are advised to adopt appropriate means to maintain an internal order as they pursue their ideal and take appropriate measures to safeguard the community from attacks by non members (Onyeocha, 12).

Nation building encourages a general co-operation that is needed in a country to develop a high scale of economic, social, cultural and political status of a country. Nation building also requires that the people should be recognized in their own right and the authority also recognized in its own right. Given this fact, it is a well established fact that nation-building involves a mutual understanding between the people and the leaders. On this note, the leaders are expected to face and shoulder its responsibilities on behalf of the people. The leaders must respect the functions and operations of other agencies beyond its jurisdiction and in return the people should take care of their own responsibilities in other to ensure national upliftment, development and prosperity. To ensure a 
progressive nation building, the people must be able to proffer genuine ideas, cultivate better dispositions and commitments relevant for promoting national goals. In the words of Onyeocha, they must readily perform their civil duties of paying their tax, maintaining a clean environment and upholding the rule of law (13).

Closely related to the concept of nation building is the idea of national development. Development is a multi dimensional concept and it involves physical and mental aspects. Thus, national development refers to the sum total of the results of the functional relationship between manual and intellectual labour of a nation in the struggle for self sustenance. It involves everything that is done within a nation with a view to uplifting the standard of men and materials (Uduigwomen and Ogbinaka, 18).

National development is evaluated on the basis of how well we approximate the attainment of our national objectives. This refers to advancement in educational level, socio-economic status, media exposure, agricultural innovations, mass production of goods and cultural awareness. These aspect of national development requires a decisive commitment and pressure. The various categories of workers set up these national objectives as their major task in nation building. To achieve these objectives, they form unions guided by laws and constitutional provisions. These unions play a very important role in nation building and national development.

\section{Impact of Trade Unionism and Collective Bargaining for Nigerian Development}

As earlier stated, nation building is not specifically placed on the shoulders of the elites or the leaders, it is a collective task and so encourages a general co-operation of all citizens in order to boost the economic, social and political status of a country. The status of trade unionism as a form of nationalist movement has contributed immensely to national development. Right from the inception of the first trade union organization, there has been series of restructuring in the various trade unions that has emerged in subsequent years. This followed from the passing of the trade union ordinance in 1938 in which there was a formal recognition of trade unionism. 
The law laid down the mode of registration of trade unions and prescribed the rights and obligations of unions in the employeremployee relationships. The law was prepared to recognize the existence of a worker's organization that fulfilled the minimum standards stipulated in the law. This gave impetus to trade union development in the country. (Ubeku, 61).

With the legal basis of the unions established, there were three major events that helped in the rapid growth of trade unionism. The first was the grant of a cost of living allowance (COLA) to government employees in June 1942, the general strike of 1945 and the Enugu shootings of 1949. Unfortunately most of the trade unions came into existence only to get the allowance and much later some of them became moribund and eventually became dissolved. This setting was to undermine the main purpose of promoting such trade unionism which was out rightly formed to cater for the welfare of the members for efficiency, effective productivity and national development.

Apart from the bad impressions created by some of these unviable unions, the emergence of the NLC produced much positive effects. The NLC became the back bone of the efficiency of these unions. They used their power to discipline any union which does not produce results. This is without prejudice to some unions like ASUU that at certain instances have accused NLC of politicizing the process of any dispute resolution between the union and the government. The result is their outright disassociation from the umbrella of NLC. However, the NLC on its inception had much problems to tackle. These include tribalism, ethnicity and nepotism, which characterized the unions during the period. These deteriorating factors have hampered the progress towards nation building. Be that as it may, the recent records of trade unionism have shown that they have contributed immensely to national development.

Experience has also shown that the NLC as the centre point of all trade unions now acts as a check on all governmental policies. In recent times, the government and its agencies have introduced moribund and non progressive policies or impositions which has caused a major set back in the workers efficiency and productivity. The NLC and other trade unions have in most times won the support 
of international organizations like the UN as regards the sustenance and adoption of the standard of workers welfare scheme, the UNESCO'S mandate that every nation must set aside $26 \%$ of their annual budget for education and the ILO's support for improved workers wages for efficient productivity. It has been reasoned that for any economic, social or political development, the welfare of the workers (skilled/professionals) must be a determinant factor which the government both state and federal must consider. Thus a good working condition and welfare package can influence the level of productivity in any country's economy. It is the collective effort of the members of these trade unions and the strength of their bargains with the government that has sustained their effectiveness and productivity.

Arguing further on the importance of collective bargaining for nation building, it has helped in no small measure to reduce the wave of strikes in the country. Collective bargaining has really helped the employers to gain insights into the problems and aspirations of the workers, while the workers on their own come to know more about the economic and technical problems of management. It is also wise to note that through the time consuming and tortuous process of collective bargaining emotionally charged work people and employers or their representatives have time to cool off and soften their problems. Thus collective bargaining some have reasoned have helped to pave way to industrial democracy in Nigeria. This is rather very controversial among many critics who are of the view that the government more often than not tends to effect the decisions of such agreements in a negative way as could be seen in many workers face off with the government or other employers. Which ever view one adopts collective bargaining promotes uniformity of incomes among those engaged in similar occupations, thus ensuring economic balance among workers. This informed the recent face off between the Academic Staff Union of Universities and the Federal Government in which the government refused to honour the union's bid for a uniform income among the lecturers in both state and federal universities.

Another basic fact on the legal enforceability of collective agreements is that there is a general rule that collective agreements are non justifiable and devoid of legal sanctions. This position is true 
because under the law, there is usually no intention to create legal relations by parties to the to the agreements. The Court in NIGERIA ARAB BANK LTD V SHUIABU rightly posited that collective agreement is at best a gentleman's agreement, an extra legal document devoid of sanctions (1999) 4NWLR (PART 186) 450.

This fact has raised further controversy to the effect that if collective agreements are not enforceable but are generally binding in honour only, what then is the purpose of the process of collective bargaining? The answer is not far fetched. In the midst of these circumstances collective agreement is very germane and parties to the agreement are expected to honour their gentlemen's agreement.

Regrettably in Nigeria, most agreements entered on behalf of the government are not usually honoured which creates a doubt on the frequent calls for negotiations in the face of any industrial dispute. The government is supposed to serve as a regulatory and mediatory body even for other sectors of the economy in their face off with their workers. They very well impute the non strike clause in the agreement but will not be willing to carry out the agreed terms in order to avoid the strike situation. This inefficiency and insensitivity of the government has caused an incessant growth of industrial disputes in Nigeria.

\section{Conclusion}

Generally, we have examined trade unionism as an aspect of nationalist movement. The effect of trade unionism in nation building calls for co-operative spirit in other to maintain a stable and sustainable economic, social and political development of the country. Although there has been records of misdirection and misplaced priority by some of the unionists, but with the recent socio-economic development in Nigeria, one can imagine the influence trade unionism could have in the country if proper guidance and support are given to them by the government or other superior authorities or agencies. This not withstanding, there is still some degree of restructuring needed in the various trade unions operating in the country. Of great importance is the level of agreements that is usually entered into between the workers union and the government or an other agency. Collective bargaining we have stated becomes the best measure in the process of dispute 
resolution that if not checked could lead to a drop in national productivity and national development in general.

Thus, apart from the ugly pursuit and non implementation or certain agreements reached during collective bargaining, trade unionism and collective bargaining have contributed immensely to nation building and national development. 


\section{References}

Erugo Sampson I. Introduction to Nigerian Labour Law. Lagos:

Mikky Communications, 1998.

Fajana, Sola. Industrial Relations in Nigeria: Theory and Features. Lagos: Labofin and Coy, 2000.

Fashoyin Tay. Industrial Relations in Nigeria (Development and Practice). Ikeja: Longman Nig, 1980.

Onyeocha, Izu M. Idealism, Politics and Nation Building. Owerri: Assumpta Press, 1994.

Ubeku, Abel K. Industrial Relations in Developing Countries: The Case of Nigeria. London: Macmillan Press, 1983.

Uduiugwomen, A.F \& Ogbinaka Karo. Philosophy and Education. Ikeja: Obaroh \& Ogbinaka Publ, 1991.

Uviehara, Egerton E. Labour Law in Nigeria. Ikeja: Malthouse Press, 2001.

Webb, Sydney \& Webb, Beatrice. Industrial Democracy. London: Longman S. GRee and Co, 1919.

Wedderburn, K.W. The Worker and the Law. London: Pengium, 1965.

Yesufu, T.N. The Dynamics of Industrial Relations: Nigeria Expereince. Ibadan: University Press, 1982. 